\title{
Ghrelin Expression in Human and Rat Fetal Lungs and the Effect of Ghrelin Administration in Nitrofen-Induced Congenital Diaphragmatic Hernia
}

\author{
MARTA SANTOS, PEDRO BASTOS, SILVIA GONZAGA, JOSÉ-MÁRIO RORIZ, MARIA J. BAPTISTA, \\ CRISTINA NOGUEIRA-SILVA, GUSTAVO MELO-ROCHA, TIAGO HENRIQUES-COELHO, \\ ROBERTO RONCON-ALBUQUERQUE JR., ADELINO F. LEITE-MOREIRA, RONALD R. DE KRIJGER, DICK TIBBOEL, \\ ROBBERT ROTTIER, AND JORGE CORREIA-PINTO
}

\begin{abstract}
Life and Health Sciences Research Institute (ICVS) [M.S., P.B., S.G., J.M.R., M.J.B., C.N.-S., G.M.-R., J.C.-P.], School of Health Sciences, University of Minho, 4709-057 Braga, Portugal; Department of Physiology [T.H.-C., R.R.-A., A.F.L.-M.], Faculty of Medicine,

University of Porto, 4200-319 Porto, Portugal; Department of Pediatric Surgery [M.S., D.T., R.R.], Department of Pathology [R.R.K.], Erasmus Medical Center, Sophia Children's Hospital, 3015 GJ Rotterdam, The Netherlands; Department of Pediatrics [T.H.-C., J.C.-P.], Division of Pediatric Surgery, Hospital São João, 4202-451 Porto, Portugal
\end{abstract}

\begin{abstract}
Ghrelin is a strong physiologic growth hormone secretagogue that exhibits endocrine and non-endocrine actions. In this study, ghrelin expression in humans and rats was evaluated throughout development of normal and hypoplastic lungs associated with congenital diaphragmatic hernia (CDH). Additionally, the effect of antenatal treatment with ghrelin in the nitrofen-induced $\mathrm{CDH}$ rat model was tested. In normal lungs, ghrelin was expressed in the primitive epithelium at early stages of development and decreased in levels of expression with gestational age. In hypoplastic lungs ghrelin was overexpressed in both human and rat CDH fetuses when compared with controls. Exogenous administration of ghrelin to nitrofentreated dams led to an attenuation of pulmonary hypoplasia of $\mathrm{CDH}$ pups. Furthermore, the growth hormone, secretagogue receptor (GHSR1a), could not be amplified from human or rat fetal lungs by RT-PCR. In conclusion, of all the lungs studied so far, the fetal lung is one of the first to express ghrelin during development and might be considered a new source of circulating fetal ghrelin. Overexpression of ghrelin in hypoplastic lungs and the effect of exogenous administration of ghrelin to nitrofen-treated dams strongly suggest a role for ghrelin in mechanisms involved in attenuation of fetal lung hypoplasia, most likely through a GHSR1a-independent pathway.

(Pediatr Res 59: 531-537, 2006)
\end{abstract}

$\mathrm{C}$ ongenital diaphragmatic hernia $(\mathrm{CDH})$ is a severe anomaly with a mean incidence of approximately 1 in 2,500 newborns. Despite research and clinical efforts to enhance treatment, the mortality rate of the most severely affected subset of $\mathrm{CDH}$ infants did not change significantly during the last decades (1). Lung hypoplasia and pulmonary hypertension associated with this pathology are the major reasons for the failure of the currently available treatments. Reversing lung

Received July 19, 2005; accepted November 2, 2005

Correspondence: Jorge Correia-Pinto, M.D., Ph.D., Escola de Ciências da Saúde, Universidade do Minho, Campus de Gualtar: CPII (piso 3), 4709-057 Braga, Portugal; e-mail: jcp@ecsaude.uminho.pt.

This project was funded by Fundação para a Ciência e a Tecnologia (POCI/SAUOBS/56428/2004). M.S. was supported by the Fundação para a Ciência e a Tecnologia (SFRH/BD/9631/2002) through the G.A.B.B.A. Programme, University of Porto, Portugal. S.G. was funded by Fundação para a Ciência e a Tecnologia (SFR/BI/9763/2003). hypoplasia surgically during the prenatal development has been attempted; however, this intervention is invasive, technically demanding and limited by the maternal and fetal risk (2). Thus, antenatal therapies that promote lung growth remain an appealing approach for fetuses with severe $\mathrm{CDH}(3,4)$.

Ghrelin is an endogenous peptide described as a strong physiologic growth hormone $(\mathrm{GH})$ secretagogue by interaction with the growth hormone secretagogue receptor 1a (GHSR1a) (5). In adults, ghrelin is predominantly produced by gastric X/A-like cells, but also by many other organs such as the kidney, the pituitary, the hypothalamus, the heart, the placenta and immune cells (6). Despite its strong GHreleasing activity, ghrelin also exhibits other prominent endocrine and nonendocrine actions (6). Ghrelin has been detected in cord blood of human fetuses from 20 wk onwards (7). During the antenatal period several organs can synthesize and secrete ghrelin even before its presence in the stomach, which only expresses ghrelin after $17 \mathrm{~d}$ post-conception $(\mathrm{dpc})$ in rats $(8,9)$. Besides its presence in the placenta $(10)$, antenatal ghrelin expression has been documented in rat (since $15 \mathrm{dpc}$ ) and human (since wk 10) pancreas $(8,11)$ and in human fetal lung as early as wk seven $(12,13)$.

The developing lung seems to be a major source of ghrelin. Significant ghrelin expression during the pseudoglandular stage of human fetal lung development (7-18 wk of gestation) was reported, suggesting that ghrelin might act as a regulator of fetal lung development by autocrine/paracrine mechanisms (13). In adult rats, it was recently demonstrated that ghrelin modulates pulmonary vascular remodeling and hypertension (14).

Abbreviations: CDH, congenital diaphragmatic hernia; dpc, days post-conception; GHSR1a, growth hormone secretagogue receptor 1a; IHC, immunochemistry; ISH, in situ hybridization; NEB, neuroendocrine bodies 
The aforementioned reports led to the hypothesis that ghrelin may be an important factor modulating lung development in CDH. In the present study, ghrelin expression in human and rat normal and hypoplastic fetal lungs was characterized. Furthermore, the effect of exogenous administration of ghrelin in a nitrofen-induced CDH rat model was tested. Our findings show that ghrelin expression is augmented in $\mathrm{CDH}$ and that exogenous administration of ghrelin is able to partially attenuate pulmonary hypoplasia in $\mathrm{CDH}$.

\section{MATERIALS AND METHODS}

Human fetal studies. Lung tissue was obtained from the archives of the Department of Pathology, Erasmus MC, Rotterdam, following approval of the experimental design and protocols by the institutional review committee. Lung tissue was derived from $12 \mathrm{CDH}$ patients including two samples following termination of pregnancy. They were all treated postnatally with standard protocols including immediate postnatal intubations, high frequency oscillatory ventilation, vasopressive drugs if needed and inhaled NO. None of the patients included in this study were subjected to extracorporeal membrane oxygenation (ECMO) therapy (Table 1) as all died of therapy-resistant respiratory insufficiency within minutes to hours after birth. As such, they were considered very severe cases of pulmonary hypoplasia. As controls, 10 normal lungs between 13.5 and 39 wk of gestation, without pulmonary abnormalities, were used. None of these patients received supplemental oxygen or mechanical ventilation. All autopsies were performed within $24 \mathrm{~h}$ of death according to the standard protocol designed by the Dutch Pediatric Pathology Society. The specimens were fixed by immersion in $4 \%$ buffered formalin, embedded in paraffin and processed for immunohistochemistry.

Immunohistochemistry (IHC). Immunostainings were performed on formalin-fixed and paraffin-embedded human tissues. Lung sections $(5 \mu \mathrm{m})$ were placed on SuperFrost@Plus slides (Menzel-Glaser, Germany). The primary antibodies were polyclonal rabbit antihuman ghrelin (H-031-30, Phoenix Pharmaceuticals, CA) and polyclonal rabbit antihuman GHSR 1a $\left(\mathrm{Cys}^{\circ}\right.$ amino acids 330-366, H-001-62, Phoenix Pharmaceuticals, CA). After dewaxing in xylene and rehydration in ethanol, the samples were incubated in 3\% hydrogen peroxide in methanol to quench the endogenous peroxidase. Antigen retrieval was achieved by boiling in $10 \mathrm{mM}$ citrate buffer, followed by cooling down to room temperature. Samples were blocked with 5\% BSA (Roche, Germany). Incubation with primary antibody occurred at $4^{\circ} \mathrm{C}$ overnight: anti-ghrelin (1:3000) and anti-GHSR1a (1:500). Negative control reactions consisted in omission of the primary antibody. Positive control reactions for ghrelin in human stomach tissue and GHSR1a in human pituitary tissue were performed. Incubation with the secondary antibody, goat anti-rabbit horseradish peroxidase conjugated serum (1:100) (P 0448, DAKO, Denmark), was carried out at room temperature for $2 \mathrm{~h}$. To visualize the peroxidase activities in sections, diaminobenzidine tetrahydrochloride (Sigma-Aldrich Co.) was used. Sections were counterstained with hematoxyline.

Table 1. Clinical information of the patients with congenital diaphragmatic hernia

\begin{tabular}{|c|c|c|c|c|c|}
\hline Case & $\begin{array}{l}\text { Gestational } \\
\text { age } \\
\text { (weeks) }\end{array}$ & $\begin{array}{l}\text { Birth } \\
\text { weight } \\
(\mathrm{g})\end{array}$ & $\begin{array}{l}\text { Lung/body } \\
\text { ratio }\end{array}$ & $\begin{array}{l}\text { Time of } \\
\text { death after } \\
\text { birth }\end{array}$ & $\begin{array}{l}\text { Clinical } \\
\text { information }\end{array}$ \\
\hline 1 & 18 & 161 & 0.012 & $\begin{array}{c}\text { Termination of } \\
\text { pregnancy }\end{array}$ & \\
\hline 2 & 21 & 416 & 0.008 & $\begin{array}{c}\text { Termination of } \\
\text { pregnancy }\end{array}$ & \\
\hline 3 & 34 & 1250 & 0.005 & Minutes & \\
\hline 4 & 36 & 2515 & 0.003 & Several hours & Pneumothorax \\
\hline 5 & 38 & 2870 & 0.005 & 30 minutes & \\
\hline 6 & 38 & 1220 & & 1 day & \\
\hline 7 & 39 & 2890 & 0.003 & 15 minutes & Pneumothorax \\
\hline 8 & 40 & 2050 & 0.006 & During labor & Trisomy 18 \\
\hline 9 & 40 & 3510 & 0.006 & Minutes & \\
\hline 10 & 40 & 3225 & 0.005 & 6 hours & \\
\hline 11 & 41 & 2765 & 0.006 & 1.5 hours & \\
\hline 12 & 42 & 3355 & 0.002 & 30 minutes & \\
\hline
\end{tabular}

Morphometric analysis. Computer-assisted morphometric analysis was performed using a StereoInvestigator program (MicroBrigthField, Williston, VT). On each slide immunoreactive bronchi were identified and traced using $20 \times$ objective to calculate the epithelial bronchial area. Additionally, the number of immunopositive cells on each bronchus was counted. Using these data the proportion of ghrelin-expressing cells per epithelial bronchial area was calculated.

Animal model and experimental design. Animal experiments were performed accordingly to the Portuguese law for animal welfare. Animals were housed in an accredited mouse house and treated as specified in the 'Guide for the Care and Use of Laboratory Animals published by the US National Institutes of Health' (National Institutes of Health Publication No.85-23, revised 1996).

Sprague-Dawley female rats (225g, Charles-River, Barcelona) were maintained in appropriate cages under controlled conditions, fed with commercial solid food and after mating they were checked for introital plugging. Forty pregnant rats at day 9.5 of gestation randomly received by gavage either a single-dose of $100 \mathrm{mg}$ of 2,4-dichorophenyl-p-nitrophenylether (nitrofen) dissolved in $1 \mathrm{~mL}$ of olive oil $(\mathrm{n}=28)$ or an equal volume of vehicle $(\mathrm{n}=$ 12). From both groups, rats were then randomly assigned to two different protocols.

Protocol 1. From the control group, fetuses were removed by caesarian section at 12.5, 15.5, 17.5, 19.5 and $21.5 \mathrm{dpc}$, whereas nitrofen-exposed fetuses were removed at $17.5,19.5$ and $21.5 \mathrm{dpc}$ since only after that gestational age we could clearly distinguish the fetuses with or without $\mathrm{CDH}$. Fetuses with 12.5 and $15.5 \mathrm{dpc}$ were processed in toto for hybridization studies. In fetuses older than $15.5 \mathrm{dpc}$, the lungs were excised and the wet weights of each lung were measured. Random left lung samples were collected and processed for in situ hybridization. Samples used for the quantification of ghrelin's expression by real time-PCR were immersed in RNAlater (Qiagen, Germany) and stored at $-80^{\circ} \mathrm{C}$.

This protocol resulted in three experimental groups: 1) control group, not exposed to nitrofen nor ghrelin; 2) nitrofen group, nitrofen-exposed fetus without diaphragmatic defect; 3 ) $\mathrm{CDH}$ group, nitrofen-exposed fetus with left diaphragmatic defect.

Protocol 2. Nitrofen-exposed dams were randomly assigned to receive ghrelin $(100 \mu \mathrm{g} / \mathrm{Kg}$, BID, s.c.) or saline between 13.5 and $17.5 \mathrm{dpc}$. An active fragment of ghrelin was obtained from the Peptides International, USA (PGH-3628-PI, Human, Rat, 1-5), with functional assay activation at $10 \mathrm{nM}$ relative to ghrelin of $96 \pm 7 \%$. Fetuses were removed at term $(21.5 \mathrm{dpc})$ and weighted. Organs that could be particularly affected in CDH (lung and heart) were excised and weighted. Random left lung samples were collected and processed for determination of total DNA and protein contents as previously described (15).

This protocol resulted in six experimental groups: 1) control + saline group, exposed neither to nitrofen nor ghrelin treated with saline; 2) nitrofen + saline group, nitrofen-exposed fetus without diaphragmatic defect treated with saline; 3) $\mathrm{CDH}+$ saline group, nitrofen-exposed fetus with left diaphragmatic defect treated with saline; 4) control + ghrelin group, not exposed to nitrofen and treated with ghrelin; 5) nitrofen + ghrelin group, nitrofenexposed fetus without diaphragmatic defect treated with ghrelin; 6) $\mathrm{CDH}+$ ghrelin group, nitrofen-exposed fetus with left diaphragmatic defect treated with ghrelin.

In situ hybridization (ISH). Digoxigenin-labeled ghrelin probe was synthesized from a $247 \mathrm{bp}$ fragment of prepro-ghrelin inserted in the pGEM-T vector. The plasmid was linearized with $\mathrm{NcoI}$ and SP6 RNA polymerase was used to synthesize the riboprobe. Tissue sections $(10 \mu \mathrm{m})$ were processed for ISH as described by Strahle et al. (16).

PCR studies. Total mRNA from each sample was extracted using the RNeasy Mini Kit Protect (Qiagen, Germany). Quantification of total mRNA was done by spectrophotometry (BioPhotometer, Eppendorf, Germany). The reverse transcription was carried out on a T-gradient thermocycler (Biometra, Germany) using the kit Superscript II (Invitrogen, U.S.A) and $100 \mathrm{ng}$ of mRNA as template.

Quantitative PCR ( $\boldsymbol{P P C R}$ ). Total cDNA was used for the relative quantification by real time-PCR of ghrelin and of the reference gene $\beta$-actin using the LightCycler (Roche, Germany). All primers used were intron-spanning (Table 2) and primer design was based on the available sequences in GenBank (NCBI-NLM-PubMed-Gene). Real time-PCR reactions consisted in SYBR Green PCR master mix (QuantiTech SYBRgreen PCR, Qiagen, Germany), $100 \mathrm{ng}$ of cDNA and $10 \mathrm{pmol}$ of each primer (Thermo Electron, Germany) in a total volume of $20 \mu \mathrm{L}$. Ghrelin amplification consisted of 15 min hot-start, 55 cycles $\left(95^{\circ} \mathrm{C} 15 \mathrm{~s}, 58^{\circ} \mathrm{C} 25 \mathrm{~s}, 72^{\circ} \mathrm{C} 20 \mathrm{~s}\right)$ and acquisition mode at $80^{\circ} \mathrm{C}$ for $5 \mathrm{~s}$. $\beta$-actin amplification was performed with $15 \mathrm{~min}$ hot-start, 55 cycles $\left(95^{\circ} \mathrm{C} 15 \mathrm{~s}, 58^{\circ} \mathrm{C} 20 \mathrm{~s}, 72^{\circ} \mathrm{C} 15 \mathrm{~s}\right)$.

Ghrelin and $\beta$-actin standard amplification curves (ST curves) were made with randomly selected cDNA samples setting at $r=0.99$. 
Table 2. Primers used for $P C R$

\begin{tabular}{|c|c|c|c|}
\hline Gene & $\begin{array}{l}\text { Accession } \\
\text { number }\end{array}$ & Primer set & $\begin{array}{l}\text { Size } \\
\text { (bp) }\end{array}$ \\
\hline hGhrelin & AB029434 & $\begin{array}{l}5^{\prime} \text {-GTT CAG GAC ATC CTC TGG-3' } \\
5^{\prime} \text {-GAG TCG TGG GAG TTG C-3' }\end{array}$ & 121 \\
\hline hGHSR1a & U60179 & $\begin{array}{l}5^{\prime} \text {-TCA GGG ACC AGA ACC AC-3' } \\
5^{\prime} \text {-GCC AGG CTC AAA GGA T-3' }\end{array}$ & 106 \\
\hline rGhrelin & NM_021669 & $\begin{array}{l}\text { 5'-TTT CTC TGC TGG GCT TTC T-3' } \\
5^{\prime} \text {-AGG CCA TGG TGT CTT CA-3' }\end{array}$ & 121 \\
\hline rGHSR1a & NM_032075 & $\begin{array}{l}\text { 5'-CAG AAC CAC AAG CAG ACA } \\
\text { GTG-3' } \\
\text { 5'-TGA TCT GAG CGA TCT CCA } \\
\text { GAG-3' }\end{array}$ & 136 \\
\hline $\mathrm{r} \beta$-actin & NM_031144 & $\begin{array}{l}\text { 5'-GAT TTG GCA CCA CAC TTT } \\
\text { CTA CA-3' } \\
\text { 5'-ACT TTG GTC ATC TTT TCA CGG } \\
\text { TTG G-3' }\end{array}$ & 114 \\
\hline
\end{tabular}

$\boldsymbol{R T}$-PCR. For human material, $100 \mathrm{ng}$ of the RT reaction was used for PCR amplification, whereas for rat material, $300 \mathrm{ng}$ were used. Standard amplification conditions were used and the PCR reactions performed in an automatic thermal cycler (MyCycler, BIO-RAD).

Statistic analysis. All quantitative data are presented as mean \pm SE. For the results of real time-PCR, a one-way ANOVA on Ranks test was applied, whereas for the evaluation of the effect on pulmonary hypoplasia of ghrelin's administration in control, nitrofen or $\mathrm{CDH}$ fetuses, a two-way ANOVA test was performed. Upon statistically significant differences, a test of StudentNewman-Keuls was selected to perform a pair-wise multiple comparisons. Statistical significance was set at $p<0.05$.

\section{RESULTS}

Immunohistochemistry in normal and $\mathrm{CDH}$ human fetal lungs. Immunohistochemistry studies showed that ghrelinproducing cells were scattered at the level of the main bronchi in all the studied cases during all the developmental stages. In normal fetal lungs (Fig. 1A), ghrelin expression was predominantly observed during the pseudoglandular and canalicular stages of lung development. In CDH lungs, the production of ghrelin was increased mainly in early stages of gestation (Fig. $1 B$ ) as confirmed by morphometric analysis from available samples (Fig. 2).

Ghrelin expression pattern during normal and $\mathrm{CDH}$ pulmonary development in rats. In situ hybridization experiments (Fig. 3A) revealed that ghrelin was expressed in the normal fetal lung during all the developmental stages studied $(12.5,15.5,17.5,19.5$ and $21.5 \mathrm{dpc})$. As shown in Fig. 3A, it was clear that ghrelin mRNA was observed in primitive lung epithelium with significant expression already at the earliest stages of rat lung development $(12.5 \mathrm{dpc})$. A maximum of ghrelin expression was observed during the pseudoglandular stage, and decreasing during subsequent stages of normal lung development.

In nitrofen-exposed groups ghrelin mRNA was detected on the pulmonary epithelium during all developmental stages studied (Fig. 3B, 17.5, 19.5 and $21.5 \mathrm{dpc}$ ). Similarly, ghrelin expression during $\mathrm{CDH}$ lung development decreased as gestational time increased, being the pseudoglandular stage representative of the maximum expression (Fig. $3 B, 17.5 \mathrm{dpc}$ ). In $\mathrm{CDH}$ lungs ghrelin expression appeared to be higher than in age-matched control lungs (Figs. $3 A, B$ ). Since no significant differences were observed between nitrofen and $\mathrm{CDH}$ groups,
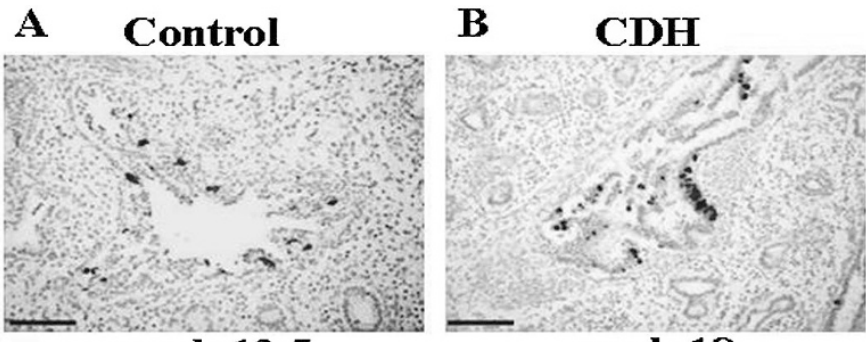

week 13.5

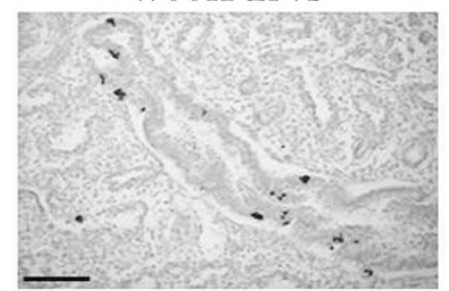

week 23

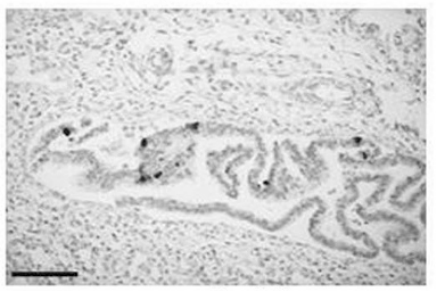

week 32

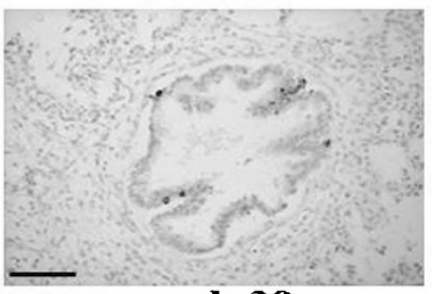

week 39

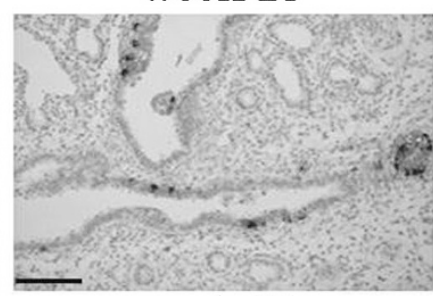

week 21

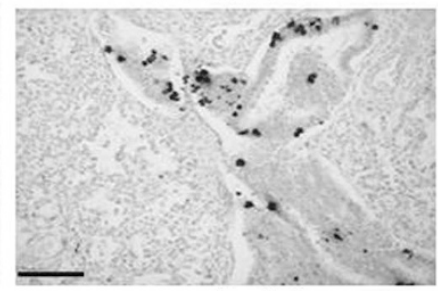

week 34

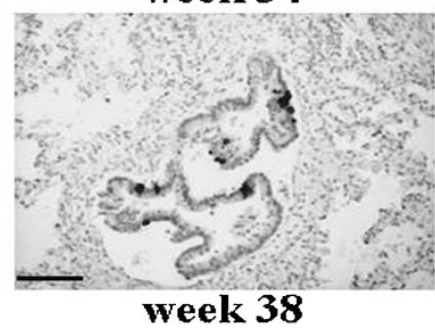

Figure 1. Developmental production of ghrelin in normal and hypoplastic $(\mathrm{CDH})$ human lungs. $A$ ) Immunohistochemistry in normal human fetal lungs. $B$ ) Immunohistochemistry in $\mathrm{CDH}$ human fetal lungs. Scale bar $=50 \mu \mathrm{m}$.

pictures depicting ISH of lungs of $\mathrm{CDH}$ fetuses are the only ones presented.

Quantitative PCR analysis. Real time-PCR experiments were performed to quantify the expression of ghrelin observed by ISH during normal and abnormal lung development (Figs. 4 and 5). The mRNA levels of $\beta$-actin were not significantly altered during gestation in any of the studied groups and were subsequently used to normalize the expression data for ghrelin. In the control group, ghrelin mRNA levels were higher in the earliest gestational ages studied (15.5 and $17.5 \mathrm{dpc}$ ) (Fig. 4). Ghrelin mRNA levels in nitrofenexposed fetuses were compared with those observed in the control group at different gestational ages (Fig. 5). A pair-wise analysis revealed that nitrofen and $\mathrm{CDH}$ groups presented significantly higher levels of ghrelin mRNA than the control group at 17.5 and $19.5 \mathrm{dpc}$, whereas at end-gestation $(21.5 \mathrm{dpc})$ ghrelin mRNA levels were appreciably higher in $\mathrm{CDH}$ group than in the control and nitrofen groups (Fig. 5). This data confirmed, therefore, the significant increase of ghrelin expression in rat hypoplastic lungs, supporting the ISH results. 


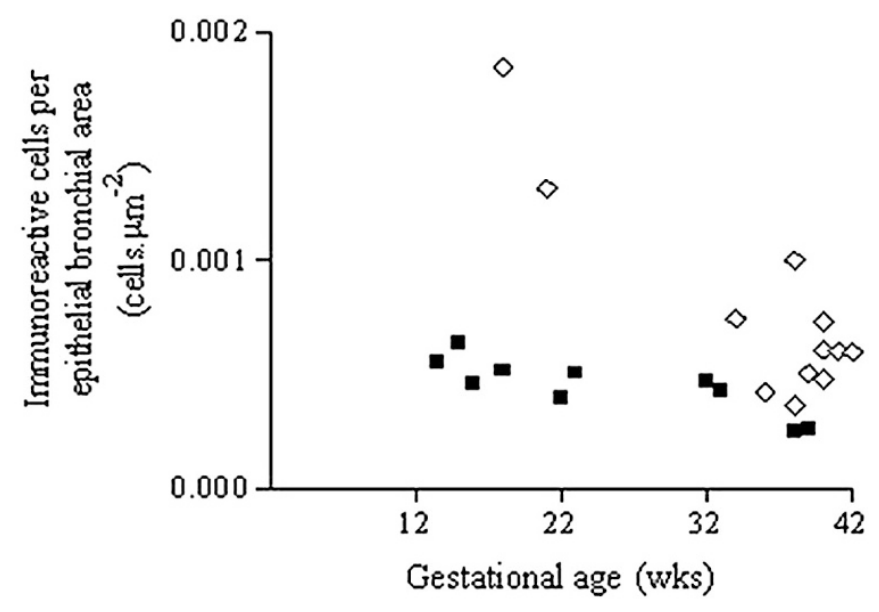

Figure 2. Results of morphometric analysis from Control (ם) and CDH $(\diamond)$ human lungs.

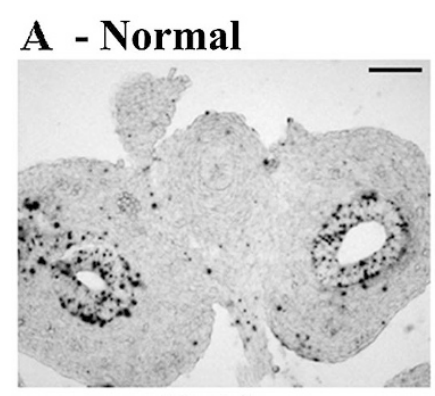

$12.5 \mathrm{dpc}$

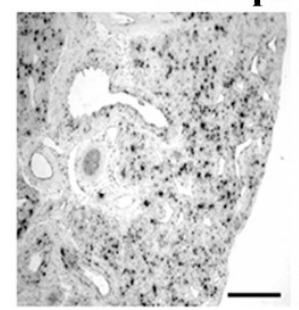

$17.5 \mathrm{dpc}$

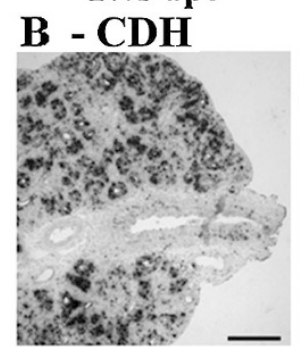

$17.5 \mathrm{dpc}$

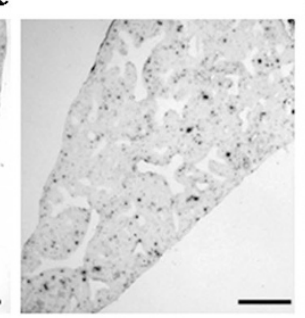

$19.5 \mathrm{dpc}$

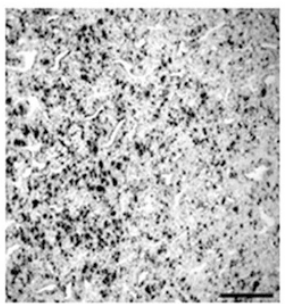

$19.5 \mathrm{dpc}$

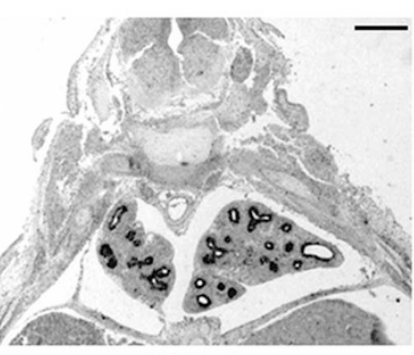

$15.5 \mathrm{dpc}$

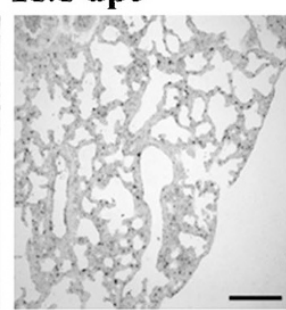

21.5 dpc

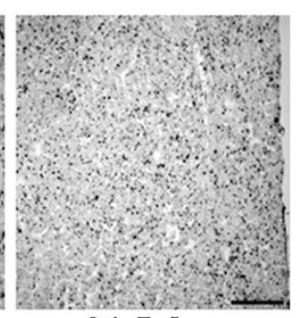

21.5 dpc
Figure 3. Ghrelin expression pattern during the development of normal and $\mathrm{CDH}$ rat lung. A) In situ hybridization in normal fetal lung. Scale bar (E12.5) $=25 \mu \mathrm{m}$. Scale bar $(\mathrm{E} 15.5)=500 \mu \mathrm{m}$. Scale bar $(\mathrm{E} 17.5,19.5$ and 21.5) $=$ $100 \mu \mathrm{m}$. B) In situ hybridization in hypoplastic CDH lung. Scale bar (E17.5, 19.5 and 21.5$)=100 \mu \mathrm{m}$.

Growth hormone secretagogue receptor expression in the fetal lung. To clarify the mechanism of action of ghrelin, GHSR1a expression was evaluated by RT-PCR in human and rat material and by IHC in human material. GHSR1a mRNA was not detected in human fetal lung (Fig. 6A). Corroborating this data, and in contrast to human pituitary samples, IHC studies also failed to detect GHSR1a in all human fetal lung

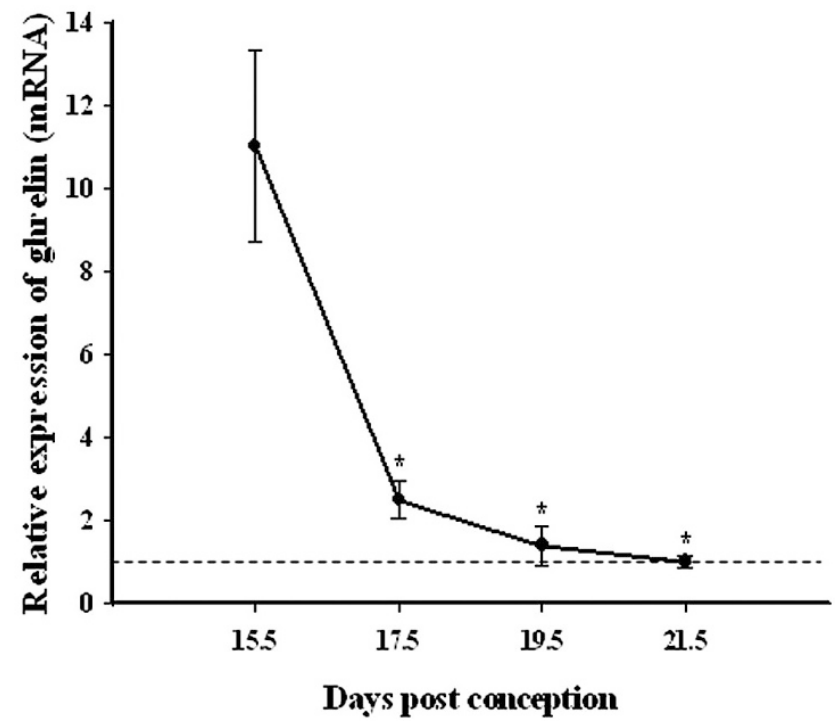

Figure 4. Ghrelin mRNA expression levels during normal fetal rat lung development, expressed in arbitrary units normalized for $\beta$-actin, obtained by real time-PCR ( $\mathrm{n}=7$ for all studied developmental ages). $p<0.05$ : versus $15.5 \mathrm{dpc}$.

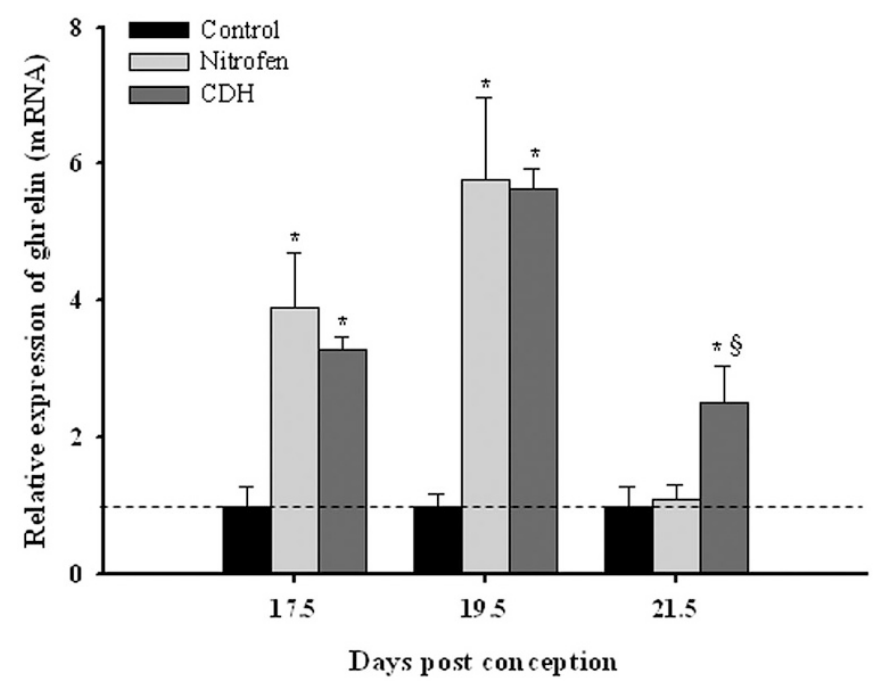

Figure 5. Ghrelin expression levels obtained by real time-PCR in nitrofeninduced $\mathrm{CDH}$ rat model. Ghrelin mRNA levels expressed in arbitrary units normalized for $\beta$-actin at day 17.5 in control group fetuses (black bars, $\mathrm{n}=$ 7), nitrofen group fetuses (light grey bars, $n=8$ ) and CDH group fetuses (dark grey bars, $n=8$ ). $p<0.05$ : * verus Control group; ${ }^{\S}$ versus Nitrofen group.

samples available. Several adult rat tissues such as pituitary, lung, brain, stomach and heart, as well as control, nitrofen and $\mathrm{CDH}$ fetal lungs from several gestational ages 17.5, 19.5, $21.5 \mathrm{dpc}$ were tested (Fig. 6B). GHSR1a was only successfully amplified in adult rat pituitary.

Effect of exogenous ghrelin administration. The previous results suggested a role for ghrelin during lung development as well as a potential modulating role in abnormal lung development. This prompted the study of the effects of exogenous administration of ghrelin between 13.5 and $17.5 \mathrm{dpc}$ (Fig. 7). All nitrofen-exposed groups treated with ghrelin presented an increase in lung-to-body weight ratio (Fig. 7). Furthermore, ghrelin-induced growth appeared to be restricted 
A

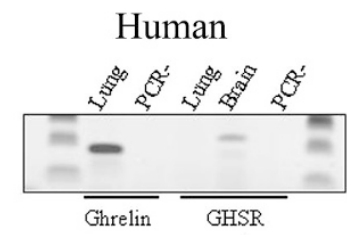

B

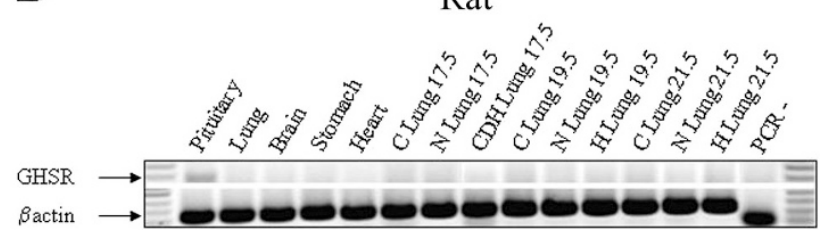

Figure 6. RT-PCR for GHSR. A) RT-PCR for GHSR1a in human material. Ghrelin was used for checking RT-PCR for fetal lung sample. B) RT-PCR for GHSR in adult rat material (Pituitary, Lung, Brain, Stomach and Heart) and in fetal rat lung (Control, Nitrofen and CDH from gestational age 17.5, 19.5, $21.5 \mathrm{dpc})$. The reference gene used for checking RT-PCR was $\beta$-actin.

to the lungs since heart-to-body weight ratio (Fig. 7) did not change upon ghrelin administration. Total protein and DNA content analyses supported the morphologic results. The nitrofen + ghrelin group revealed increased total protein $(0.50 \pm 0.1 \mathrm{mg} / \mathrm{g})$ and DNA content $(17.3 \pm 1 \mu \mathrm{g} / \mathrm{g})$ when compared with the nitrofen + saline group $(0.42 \pm 0.1 \mathrm{mg} / \mathrm{g}$ protein; $15.0 \pm 2 \mu \mathrm{g} / \mathrm{g}$ DNA; $p<0.05)$. Similar observations were obtained for the $\mathrm{CDH}+$ ghrelin $(0.35 \pm 0.2 \mathrm{mg} / \mathrm{g}$ protein; $13.6 \pm 2 \mu \mathrm{g} / \mathrm{g}$ DNA; $p<0.05)$ and $\mathrm{CDH}+$ saline groups $(0.26 \pm 0.1 \mathrm{mg} / \mathrm{g}$ protein; $11.6 \pm 2 \mu \mathrm{g} / \mathrm{g}$ DNA). No significant statistical differences in the protein/DNA ratio between the ghrelin-treated and nontreated groups were detected.

\section{DISCUSSION}

The present study revealed that in normal fetal lungs ghrelin was expressed in primitive epithelial cells as early as the pseudoglandular stage of development with decreasing levels of expression throughout gestation. Although a similar expression pattern was observed in hypoplastic lungs, ghrelin was overexpressed in the $\mathrm{CDH}$ lungs from human and rat. Exog-

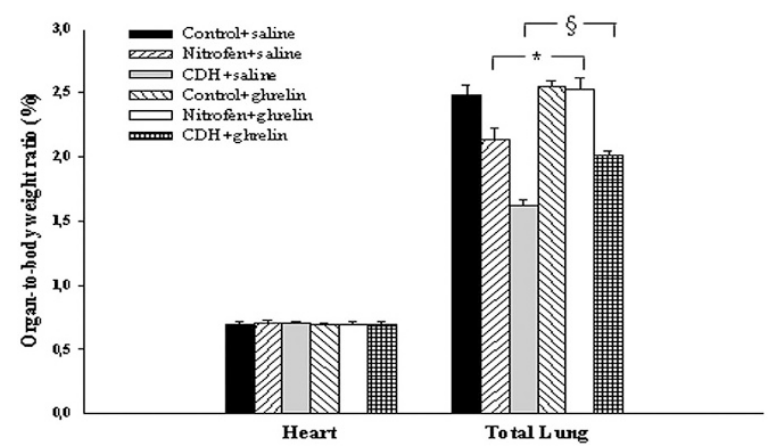

Figure 7. Effect of ghrelin administration to nitrofen-treated dams between 13.5 and $17.5 \mathrm{dpc}$. Organ-to-body weight ratio for all experimental groups was determined. Control + saline $(\mathrm{n}=27)$; Control + ghrelin $(\mathrm{n}=13)$; Nitrofen + saline $(\mathrm{n}=20)$; Nitrofen + ghrelin $(\mathrm{n}=24) ; \mathrm{CDH}+$ saline $(\mathrm{n}=23)$; $\mathrm{CDH}+\operatorname{ghrelin}(\mathrm{n}=34) \cdot p<0.05: *$ versus Nitrofen + saline group; ${ }^{\S}$ versus $\mathrm{CDH}+$ saline group. enous administration of ghrelin to nitrofen-treated dams led to an attenuation of the CDH-related pulmonary hypoplasia. This effect is mediated most likely through a GHSR1a-independent pathway since GHSR1a was not detected in human and rat fetal lungs.

Ghrelin expression was characterized in human and rat normal and hypoplastic lungs. Human lung tissue was derived from $\mathrm{CDH}$ patients with severe pulmonary hypoplasia, as well as from the available controls. For rat studies, the nitrofeninduced $\mathrm{CDH}$ model was used since it is the one that best mimics the human disease $(15,17,18)$. Nitrofen administration leads to an equal interference in the growth of both lungs even before the diaphragm development occurs. After the establishment of the diaphragmatic defect, presumably from $16 \mathrm{dpc}$ onwards, ipsilateral lung development is impaired due to the herniated abdominal organs (17).

In humans, the observations from Volante et al. (13) were confirmed. Ghrelin positive cells appeared as isolated cells or as small clusters in normal fetal epithelium (13). In normal rat fetal lungs, ghrelin expression was observed as early as $12.5 \mathrm{dpc}$ with ghrelin-positive cells appearing at the epithelial level of the proximal bronchi. Furthermore, it was shown that ghrelin expression levels decreased throughout gestation. Besides the placenta (10), the developing lung and pancreas express ghrelin earlier than other organs previously studied, suggesting that branching organs are the main sources of circulating fetal ghrelin. Although it is known that ghrelin knock-out mice do not show significant lung abnormalities (19), the early presence of ghrelin expressing cells, as well as their prominent number in the fetal lung, may indicate a developmental role for ghrelin.

In human or rat $\mathrm{CDH}$-associated hypoplastic fetal lungs, ghrelin expression remained restricted to the epithelium. The number of ghrelin-positive cells per epithelial bronchial area in human lung was increased mainly in early stages of lung development suggesting overexpression of ghrelin in $\mathrm{CDH}$ lungs. In experimental $\mathrm{CDH}$ rat lungs ghrelin mRNA levels were significantly higher than in lungs of age-matched controls. In humans, age-matched statistical comparisons could not be performed due to the reduced number of available samples representative of each fetal lung gestational stage.

During normal embryonic development ghrelin may be acting via GH-dependent (endocrine) or independent (paracrine) pathways. There are several reports suggesting that GH-independent pathways, acting by autocrine/paracrine mechanisms via GHSR1a, might be more relevant during development than the GH-dependent pathways (13). However, GHSR1a was not detected in human or rat fetal lungs rendering unlikely the hypothesis that ghrelin acts in fetal lung through GHSR1a. Despite this evidence, the possibility that ghrelin acts by autocrine/paracrine mechanisms via other receptor(s) than GHSR1a cannot be excluded, as it has been suggested in other tissues $(20,21)$. Nevertheless, the possibility of involvement of $\mathrm{GH}$-dependent endocrine pathways cannot be ruled out. In fact, ghrelin expression in fetal lung reaches its peak at mid-gestation, when serum $\mathrm{GH}$ levels also reach maximal values (22). The presence of GH mRNA in the fetal rat lung during pseudoglandular stage, was recently documented (23), 
and it has been suggested that fetal GH can interact with $\mathrm{GH}$ receptors existent in fetal lung epithelium $(24,25)$ and modulate lung growth by interfering with IGF activity while increasing IGFBP-2 (26). Ghrelin produced in the lung may represent one of the major factors responsible for the mid-gestational peak of $\mathrm{GH}$, hence modulating fetal lung development.

Pulmonary hypoplasia associated with $\mathrm{CDH}$ may be interpreted as a consequence of the decrease in pulmonary growth factors. However, this study reported a paradoxical increase in ghrelin expression during abnormal CDH lung development. There are two possible interpretations: i) it is a consequence of lung immaturity or ii) it represents a compensatory response of the hypoplastic lung attempting to recover to normal levels of lung growth. Previous reports have also shown increased levels of some growth factors in the $\mathrm{CDH}$ lung toward the end of gestation (27-29). Most of these results were interpreted as an indicator of lung immaturity in $\mathrm{CDH}$ based on the fact that growth factor levels of hypoplastic lungs at end-gestation were similar to the ones observed in normal fetal lung during early-gestation $(27,29)$. In this study, however, ghrelin levels were always higher in the $\mathrm{CDH}$ groups than in age-matched controls in all studied gestational ages. Consequently, ghrelin overexpression in hypoplastic lungs does not seem to relate with lung immaturity.

The observed ghrelin-positive cells in the lung have been described as pulmonary neuroendocrine cells (PNEC) (13). Neuroepithelial bodies (NEB) are clusters of innervated PNEC (30) distributed throughout the airway mucosa. NEB are the site of amines and peptides production (31) that seem to have an important role during lung development as well as during neonatal adaptation $(32,33)$ acting as sensors (i.e. hypoxia) (30,34,35). IJsselstijn et al. (32) described increased expression in $\mathrm{CDH}$ infants of bombesin, a NEB-produced molecule that regulates lung development (36). These authors (37) also reported that the number of NEB per surface area of lung parenchyma was increased at end-gestation in $\mathrm{CDH}$ lungs in the $\mathrm{CDH}$ rat model, interpreting these findings as a compensatory mechanism related to impaired lung development. The aforementioned observations, as well as our own data, prompt us to hypothesize that NEB could act as sensors of lung growth. Under these circumstances, ghrelin should be considered as a growth factor released in response to the pulmonary hypoplasia associated with $\mathrm{CDH}$.

The effect of exogenous ghrelin administration to normal and nitrofen-exposed dams was tested. The gestational age selected for ghrelin administration was based on the observed maximal expression during the pseudoglandular stage. The ghrelin dose was selected as previously defined for s.c. injection (14). Experimental observations indicated that in nitrofenexposed pups, ghrelin administration could normalize lung growth in the nitrofen group and increase lung-to-body weight ratio in the $\mathrm{CDH}$ group by $18 \%$. The potential clinical relevance of this effect should be emphasized, since such an increase in lung parenchyma can be determinant in providing a better adaptation of $\mathrm{CDH}$ fetus to extra-uterine life. Ghrelin effect seemed lung-specific, since heart-to-body weight ratio of the newborn pups was not altered. Interestingly, lung-tobody weight ratio in normal fetus was not significantly changed by ghrelin either. Therefore, ghrelin overexpression in $\mathrm{CDH}$ should not be interpreted as a causative factor of lung underdevelopment, but rather a consequence of lung hypoplasia, a countermeasure that elicits attenuation of lung underdevelopment in $\mathrm{CDH}$ fetuses.

\section{CONCLUSION}

In conclusion, by analyzing human and rat fetuses, a peak of ghrelin expression during the pseudoglandular stage of normal lung development was reported. Ghrelin overexpression in hypoplastic lungs and the effect of ghrelin exogenous administration to nitrofen-treated dams, suggests a role for ghrelin in the mechanisms involved in attenuating $\mathrm{CDH}$ associated lung hypoplasia.

Acknowledgments. We would like to thank Dr. TenaSempere for providing the plasmid with ghrelin for the riboprobe synthesis.

Note added in proof: After this manuscript had been accepted, a paper describing abnormalities in norepinephrine and respiratory systems in Mecp2-/y mice was published: Viemari JC, Roux JC, Tryba AK, Saywell V, Burnet H, Pena F, Zanella S, Bevengut M, Barthelemy-Requin M, Herzing LB, Moncla A, Mancini J, Ramirez JM, Villard L, Hilaire G 2006 Mecp2 deficiency disrupts norepinephrine and respiratory systems in mice. J Neurosci 2005 Dec 14;25:1152111530.

\section{REFERENCES}

1. Stege G, Fenton A, Jaffray B 2003 Nihilism in the 1990s: the true mortality of congenital diaphragmatic hernia. Pediatrics 112:532-535

2. Harrison MR, Keller RL, Hawgood SB, Kitterman JA, Sandberg PL, Farmer DL, Lee H, Filly RA, Farrell JA, Albanese CT 2003 A randomized trial of fetal endoscopic tracheal occlusion for severe fetal congenital diaphragmatic hernia N Engl J Med 349:1916-1924

3. Baptista MJ, Melo-Rocha G, Pedrosa C, Gonzaga S, Teles A, Estevao-Costa J, Areias JC, Flake AW, Leite-Moreira AF, Correia-Pinto J 2005 Antenatal Vitamin A administration attenuates lung hypoplasia by interfering with early instead late determinants of lung underdevelopment in congenital diaphragmatic hernia. J Pediatr Surg 40:658-665

4. Li J, Hu T, Liu W, Xiang B, Jiang X 2004 Effect of epidermal growth factor on pulmonary hypoplasia in experimental diaphragmatic hernia. J Pediatr Surg 39:37-42

5. Kojima M, Hosoda H, Date Y, Nakazato M, Matsuo H, Kangawa K 1999 Ghrelin is a growth-hormone-releasing acylated peptide from stomach. Nature 402:656-660

6. Wang G, Lee HM, Englander E, Greeley GH 2002 Ghrelin-not just another stomach hormone. Regul Pept 105:75-81

7. Cortelazzi D, Cappiello V, Morpurgo PS, Ronzoni S, Nobile De Santis MS, Cetin I, Beck-Peccoz P, Spada A 2003 Circulating levels of ghrelin in human fetuses. Eur J Endocrinol 149:111-116

8. Chanoine JP, Wong AC 2004 Ghrelin gene expression is markedly higher in fetal pancreas compared with fetal stomach: effect of maternal fasting. Endocrinology $145: 3813-3820$

9. Hayashida T, Nakahara K, Mondal MS, Date Y, Nakazato M, Kojima M, Kangawa K, Murakami N 2002 Ghrelin in neonatal rats: distribution in stomach and its possible role. J Endocrinol 173:239-245

10. Gualillo O, Caminos J, Blanco M, Garcia-Caballero T, Kojima M, Kangawa K, Dieguez C, Casanueva F 2001 Ghrelin, a novel placental-derived hormone. Endocrinology 142:788-794

11. Wierup N, Svensson H, Mulder H, Sundler F 2002 The ghrelin cell: a novel developmentally regulated islet cell in the human pancreas. Regul Pept 107:63-69

12. Rindi G, Necchi V, Savio A, Torsello A, Zoli M, Locatelli V, Raimondo F, Cocchi D, Solcia E 2002 Characterization of gastric ghrelin cells in man and other mammals: studies in adult and fetal tissues. Histochem Cell Biol 117:511-519

13. Volante M, Fulcheri E, Allia E, Cerrato M, Pucci A, Papotti M 2002 Ghrelin expression in fetal, infant, and adult human lung. J Histochem Cytochem 50:1013-1021

14. Henriques-Coelho T, Correia-Pinto J, Roncon-Albuquerque R Jr., Baptista MJ, Lourenco AP, Oliveira SM, Brandao-Nogueira A, Teles A, Fortunato JM, LeiteMoreira AF 2004 Endogenous production of ghrelin and beneficial effects of its exogenous administration in monocrotaline-induced pulmonary hypertension. Am J Physiol Heart Circ Physiol 287:H2885-H2890 
15. Correia-Pinto J, Baptista MJ, Pedrosa C, Estevao-Costa J, Flake AW, Leite-Moreira AF 2003 Fetal heart development in the nitrofen-induced CDH rat model: the role of mechanical and nonmechanical factors. J Pediatr Surg 38:1444-1451

16. Strahle U, Blader P, Adam J, Ingham PW 1994 A simple and efficient procedure for non-isotopic in situ hybridization to sectioned material. Trends Genet 10:75-76

17. Keijzer R, Liu J, Deimling J, Tibboel D, Post M 2000 Dual-hit hypothesis explains pulmonary hypoplasia in the nitrofen model of congenital diaphragmatic hernia. Am J Pathol 156:1299-1306

18. Migliazza L, Xia H, Diez-Pardo JA, Tovar JA 1999 Skeletal malformations associated with congenital diaphragmatic hernia: experimental and human studies. J Pediatr Surg 34:1624-1629

19. Sun Y, Ahmed S, Smith RG 2003 Deletion of ghrelin impairs neither growth nor appetite. Mol Cell Biol 23:7973-7981

20. Baldanzi G, Filigheddu N, Cutrupi S, Catapano F, Bonissoni S, Fubini A, Malan D,Baj G, Granata R, Broglio F, Papotti M, Surico N, Bussolino F, Isgaard J, Deghenghi R, Sinigaglia F, Prat M, Muccioli G, Ghigo E, Graziani A 2002 Ghrelin and des-acyl ghrelin inhibit cell death in cardiomyocytes and endothelial cells through ERK1/2 and PI 3-kinase/AKT. J Cell Biol 159:1029-1037

21. Muccioli G, Pons N, Ghe C, Catapano F, Granata R, Ghigo E 2004 Ghrelin and des-acyl ghrelin both inhibit isoproterenol-induced lipolysis in rat adipocytes via a non-type 1a growth hormone secretagogue receptor. Eur J Pharmacol 498:27-35

22. Wollmann HA 2000 Growth hormone and growth factors during perinatal life. Horm Res 53:50-54

23. Beyea JA, Olson DM, Harvey S 2005 Growth hormone expression in the perinatal and postnatal rat lung. Dev Dyn 232:1037-1046

24. Edmondson SR, Werther GA, Russell A, LeRoith D, Roberts CT, Beck F 1995 Localization of growth hormone receptor/binding protein messenger ribonucleic acid (mRNA) during rat fetal development: relationship to insulin-like growth factor-I mRNA. Endocrinology 136:4602-4609

25. Garcia-Aragon J, Lobie PE, Muscat GE, Gobius KS, Norstedt G, Waters MJ 1992 Prenatal expression of the growth hormone $(\mathrm{GH})$ receptor/binding protein in the rat: a role for GH in embryonic and fetal development? Development 114:869-876

26. Batchelor DC, Lewis RM, Breier BH, Gluckman PD, Skinner SJ 1998 Fetal rat lung epithelium has a functional growth hormone receptor coupled to tyrosine kinase activity and insulin-like growth factor binding protein-2 production. J Mol Endocrinol 21:73-84

27. Guarino N, Solari V, Shima H, Puri P 2004 Upregulated expression of EGF and TGF-alpha in the proximal respiratory epithelium in the human hypoplastic lung in congenital diaphragmatic hernia. Pediatr Surg Int 19:755-759

28. Ohshiro K, Miyazaki E, Taira Y, Puri P 1998 Upregulated tumor necrosis factoralpha gene expression in the hypoplastic lung in patients with congenital diaphragmatic hernia. Pediatr Surg Int 14:21-24

29. Unemoto K, Sakai M, Shima H, Guarino N, Puri P 2003 Increased expression of ICAM-1 and VCAM-1 in the lung of nitrofen-induced congenital diaphragmatic hernia in rats. Pediatr Surg Int 19:365-370

30. Adriaensen D, Brouns I, Van Genechten J, Timmermans JP 2003 Functional morphology of pulmonary neuroepithelial bodies: extremely complex airway receptors. Anat Rec A Discov Mol Cell Evol Biol 270:25-40

31. Cutz E, Gillan JE, Perrin DG 1995 Pulmonary neuroendocrine cell system: an overview of cell biology and pathology with emphasis on pediatric lung disease. In: Askin FB, Langston C, Rosenberg HS, and Berstein J. (eds) Perspectives in Pediatric Pathology Basel: Karger, p. 32-70.

32. Ijsselstijn H, Gaillard JL, de Jongste JC, Tibboel D, Cutz E 1997 Abnormal expression of pulmonary bombesin-like peptide immunostaining cells in infants with congenital diaphragmatic hernia. Pediatr Res 42:715-20

33. Sunday ME, Kaplan LM, Motoyama E, Chin WW, Spindel ER 1988 Gastrinreleasing peptide (mammalian bombesin) gene expression in health and disease. Lab Invest 59:5-24

34. Van Lommel A 2001 Pulmonary neuroendocrine cells (PNEC) and neuroepithelial bodies (NEB): chemoreceptors and regulators of lung development. Paediatr Respir Rev 2:171-176

35. Youngson C, Nurse C, Yeger H, Cutz E 1993 Oxygen sensing in airway chemoreceptors. Nature 365:153-155

36. King KA, Torday JS, Sunday ME 1995 Bombesin and [Leu8]phyllolitorin promote fetal mouse lung branching morphogenesis via a receptor-mediated mechanism. Proc Natl Acad Sci U S A 92:4357-4361

37. IJsselstijn H, Perrin DG, de Jongste JC, Cutz E, Tibboel D 1995 Pulmonary neuroendocrine cells in neonatal rats with congenital diaphragmatic hernia. J Pediatr Surg 30:413-415 